\title{
Effect of supplementary feeding on reproductive success of hihi (stitchbird, Notiomystis cincta) at a mature forest reintroduction site
}

\author{
Lydia R. Doerr ${ }^{*}$, Kate M. Richardson ${ }^{2,3,4}$, John G. Ewen ${ }^{3}$ and Doug P. Armstrong ${ }^{2}$ \\ ${ }^{1}$ Department of Biology \& Microbiology, University of Wisconsin, Oshkosh, Wisconsin, USA \\ ${ }^{2}$ Wildlife Ecology Group, Massey University, Palmerston North, New Zealand \\ ${ }^{3}$ Institute of Zoology, Zoological Society of London, Regent's Park, London, UK \\ ${ }^{4}$ Present address: Hawai 'i Endangered Bird Conservation Program, San Diego Zoo Global, PO Box 39, Volcano, HI 96785, USA \\ *Author for correspondence (Email: doerr.lydia@gmail.com)
}

Published online: 18 October 2016

\begin{abstract}
Supplementary feeding has proven to be a successful conservation tool for many species, including New Zealand's hihi (stitchbird, Notiomystis cincta). Previous research has shown supplementary feeding to substantially increase hihi reproductive success at regenerating forest sites, but suggested that it would have reduced benefit in mature forest habitat. Here we report the first direct test of the effect of supplementary feeding on hihi reproductive success in mature forest, using data from the recently reintroduced population at Maungatautari Ecological Island. Eight feeder-using females and nine non-feeder-using females were monitored during the 2012/13 breeding season at Maungatautari to determine how feeder use affected reproductive success (nest success, number of first-clutch fledglings per female and total number of fledglings per female). Feeder-using females fledged 3.7 times as many fledglings as non-feeder-using females in their first-clutch attempts (95\% CI 1.6-8.8), and 1.8 times as many fledglings in total (95\% CI 1.0-3.5). No feeder-using female experienced nest failure, whereas 7 of the 16 nest attempts of non-feeder-using females failed to fledge any young. The results suggest that, counter to expectations, supplementary feeder use has a significant impact on reproductive success in mature forest habitat. At least for Maungatautari, providing supplementary food in mature forest habitat appears to greatly reduce the probability of hihi nest failure, and increases the number of young a female can fledge.
\end{abstract}

Keywords: breeding success; conservation management; food supplementation; stitchbird; translocation

\section{Introduction}

Threatened species often require supportive management in order to recover populations and sustain positive population growth (e.g. Shea 1998; Blanco et al. 2011; Ewen et al. 2015). The need for supportive management can be particularly true for reintroduced populations because their small population size during establishment makes them particularly vulnerable to stochastic extinction and potentially Allee effects (Converse et al. 2013). Supplementary feeding has proven to be an effective technique for management, both for reintroduced and natural populations of a wide variety of mammal and bird species (Ziegltrum 2008; Cortés-Avizanda et al. 2010; Makan et al. 2014), encouraging population growth through both increased reproduction (e.g. Hansen 1987; Pérez-González et al. 2006; Schoech et al. 2008) and survival (e.g. López-Bao et al. 2010).

The use of supplementary food is not always accompanied by critical evaluation of its need or success at improving population growth (Oro et al. 2008; Blanco et al.2011) however, and this has led to supplementary feeding being criticised as a dogmatic approach in conservation (Martinez-Abrain \& Oro 2013). In addition, some studies have reported negative effects on the species being fed, or on other species in the wider recipient ecosystem (Pérez-González et al. 2010; Blanco et al. 2011; Robb et al. 2011). In addition, conservation of threatened species is costly and funding is limited; so managers need to critically evaluate how resources are allocated against the objectives of management (Armstrong et al. 2007). For example, supplementary feeding in high quality habitats where species are not food limited would be a misallocation of resources.

Supplementary feeding is an important component of the management of reintroduced hihi populations (Armstrong etal. 2007; Chauvenet et al.2012). Hihi became extinct on mainland New Zealand by the late 1800 s, with a single population surviving on Te Hauturu-o-Toi (Little Barrier Island; hereafter Hauturu) (Buller 1888; Innes et al. 2010). The conservation of this threatened species primarily focused on reintroductions to islands and other reserves free of mammalian predators. The poor success of initial reintroductions (Taylor et al. 2005) in combination with behavioural data (Castro 1995) suggested that food supply was inadequate at release sites, leading to food supplementation experiments in subsequent reintroductions (Armstrong \& Perrott 2000; Armstrong \& Ewen 2001; Armstrong et al. 2007). Strong evidence of food limitation at some release sites (Armstrong et al. 2007; Chauvenet et al. 2012) and the growth of some populations under supplementary feeding, has led to supplementary feeding being conducted at all reintroduction sites since 2000 . However, because food limitation is thought to be associated with regenerating forest (Castro 1995), supplementary food is expected to have a lesser impact at sites dominated by mature forest, and therefore may be unnecessary.

A comparison of reproduction data among sites varying in maturity has given some support to this site maturity hypothesis (Makan et al. 2014). For example, only about a third of Kapiti Island has remnant tall forest that has not been logged since the early 1900s, and this is where the hihi 
population has established. This area consists of six forest types: kohekohe (Dysoxylum spectabile), kānuka (Kunzea ericoides), a mix of tawa (Beilschmiedia tawa) and hīnau (Elaeocarpus dentatus), five-finger (Pseudopanax arboreus), māhoe (Melicytus ramiflorus), and a mix of tawa and kāmahi (Weinmannia racemosa)(for more detail see Makan et al. 2014); and supplementary feeding of hihi is required (Chauvenet et al. 2012). Tiritiri Matangi (dominated by replanted pōhutukawa (Metrosideros excelsa), taraire (Beilschmiedia tarairi), kohekohe and puriri (Vitex lucens)) and Mokoia (dominated by māhoe, mapou (Myrsine australis) and cabbage tree (Cordyline australis)) Islands are in intermediate stages of forest succession with low canopies ( $<10 \mathrm{~m}$ high) and a less diverse understory. Both of these island populations of hihi require supplementary feeding for persistence (Armstrong \& Perrott 2000; Armstrong \& Ewen 2001; Armstrong et al. 2007). Hauturu remains the only hihi population that persists without supplementary feeding. A more detailed description and comparison of habitat between sites with hihi is provided by Makan et al. (2014).

This study evaluated the effects of supplementary feeding on female hihi reproductive success at Maungatautari Ecological Island (hereafter Maungatautari), which consists primarily of mature forest (McQueen et al. 2004). More than any other release site, Maungatautari's mature forest makes it the most similar habitat to Hauturu. Hauturu's remoteness has meant its diverse old-growth tall forest ( $>20 \mathrm{~m}$ high) has remained mostly undisturbed for more than 150 years. Its understory is shaded primarily by rata (Metrosideros robusta), tawa, kauri (Agathis australis), pōhutukawa and kānuka forest (Makan 2006). Maungatautari is similar to Hauturu in its size (3363 vs 3083 ha), forest maturity ( $>20 \mathrm{~m}$ high), and canopy composition (rimu (Dacrydium cupressinum), rata, tawa, rewarewa (Knightia excelsa), pukatea (Laurelia novaezelandiae)) (McQueen et al. 2004). Therefore, Maungatautari is thought to represent the most likely site to establish a second hihi population that is not dependent on supplementary feeding (Ewen et al. 2011). Here, we aim to assess whether supplementary feeding has a lesser impact on reproductive success than we would predict from our knowledge of other reintroduction sites characterised by younger vegetation. Using a natural experiment, we compared the reproductive success (nest success, and number of fledglings produced in both first clutches and overall during the breeding season) of breeding females that utilised supplementary food, with those that did not. Maungatautari offers habitat of comparable quality to individuals nesting both near to and distant from the supplementary feeders. Estimates from both groups are compared to literature reporting reproductive success from other hihi populations (nest success and number of fledglings produced; Makan et al. 2014). We also incorporated age as a variable into our analysis, because previous studies on hihi found age to influence reproductive success (Armstrong et al. 2002; Low et al. 2007).

\section{Methods}

The hihi is the sole representative of the Notiomystidae family (Ewen et al. 2006; Driskell et al. 2007) and are small (males c. $40 \mathrm{~g}$, females c. $32 \mathrm{~g}$ ) sexually-dimorphic cavity-nesters (Higgins et al. 2001). Although hihi are considered to be nectarivorous/frugivorous, invertebrates also account for a substantial portion of their diet, particularly during the breeding season (September to February). Hihi are generally socially monogamous, with females carrying out nest construction and incubation ( $\sim 15$ days), and both sexes feeding young in the nest (the male to varying degrees; Low et al. 2006). Fledging occurs at $\sim 28$ days.

\section{Study site}

Maungatautari (3363 ha, $797 \mathrm{~m}$ a.s.1.) is a volcanic cone located in the Waikato region of the North Island of New Zealand $\left(38^{\circ} 03^{\prime} 08^{\prime \prime} \mathrm{S}, 175^{\circ} 33^{\prime} 58^{\prime \prime} \mathrm{E}\right)$. Large-scale logging of the site has been restricted to the lower slopes, leaving the slopes above $\sim 300 \mathrm{~m}$ a.s.l. covered with largely intact mature broadleaf-podocarp forest (McQueen et al. 2004). The surrounding landscape is dominated by dairy pasture, offering little to no habitat for native species, essentially making Maungatautari an island. The construction of a $47 \mathrm{~km}$ Xcluder ${ }^{\mathrm{TM}}$ pest-proof fence around the reserve has allowed for the eradication of all introduced mammals, except for mice (Mus musculus), and low numbers of rabbits (Oryctolagus cuniculus) and hares (Lepus europaeus) (Richardson \& Ewen 2016). Six supplementary feeders (20\% sugar water solution) are provided for hihi, all within $150 \mathrm{~m}$ of the release site (Fig. 1). Both the supplementary feeders and release site are located in the southern sub-enclosure; this release site was selected largely because it provides easiest access for the general public and is the site of the most commonly used public walking tracks. This location also facilitates the regular maintenance of the supplementary feeders by staff and volunteers. Species distribution modelling has shown that hihi at Maungatautari tend to select breeding territories in close proximity to streams, and the majority of nests are located in pukatea (Richardson \& Ewen 2016) regardless of whether nesting close or far from feeders. Given the similarity in habitat selection for all hihi at Maungatautari we assume little difference between feeder and non-feeder user territories.

Over a series of three translocations, a total of 155 hihi (82 males, 73 females) were released at Maungatautari between 2009 and 2011. To maximise genetic diversity, birds were sourced from both Hauturu (20) and Tiritiri Matangi Island (135). By 2012/13, there were 68 banded hihi in the population, and seven known unbanded hihi (see Richardson \& Ewen 2016 for details of monitoring at the site). None of the unbanded hihi were known to use supplementary feeders. Of the banded population, 26 (16 males, 10 females) were translocated (founders), and of these 17 (13 males, 4 females) were known feeder-users. The remaining 42 (26 males, 16 females) were hihi that had been bred at Maungatautari, and of these 16 (12 males, 4 females) were known feeder-users. Founder hihi were known to travel from one side of the reserve to the other to access supplementary food $(>5 \mathrm{~km})$; however, Maungatautari-bred feeder-using hihi were largely those breeding within relatively close proximity of the feeders $(<1 \mathrm{~km})$. The use of distant feeders by founder hihi may be a result of these birds having greater awareness of the feeder locations as they were released close to them. In contrast, hihi with both natal and first breeding sites several kilometres from supplementary feeders likely never encountered them during natal dispersal movements and therefore were less likely to be aware of their presence to learn to use them.

\section{Sampling design and data collection}

Data were collected during the 2012/13 breeding season (September to March). Thirty-minute observations at each 


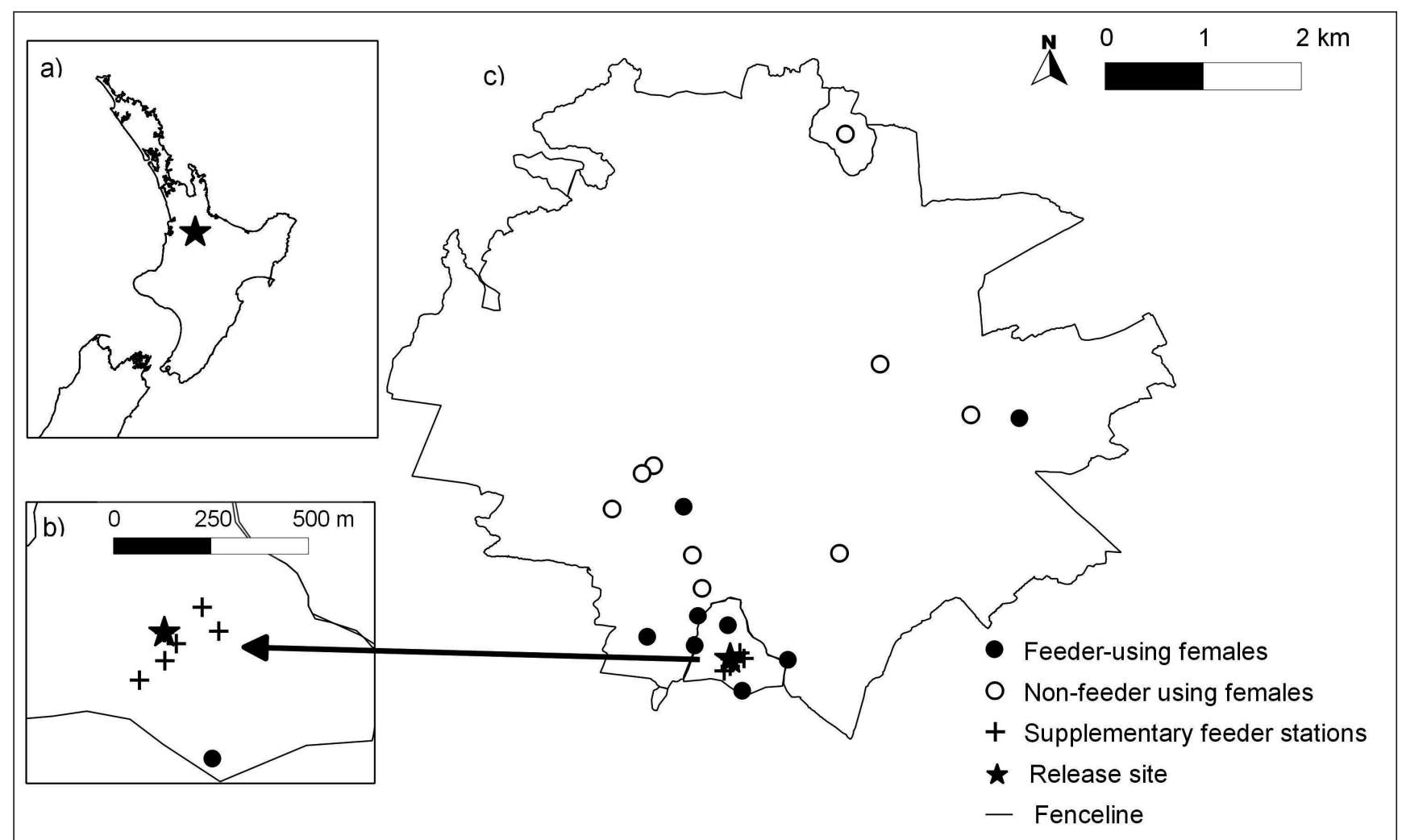

Figure 1. Map showing: (a) location of Maungatautari Ecological Island (MEI) in the North Island of New Zealand, (b) locations of sugar-water feeding stations which are restricted to the southern sub-enclosure of MEI, and (c) locations of hihi females in the 2012/13 breeding season at MEI.

feeder were performed throughout the study approximately three to four times per week to quantify which individuals were feeder-users. Feeder observations were carried out at different times of the day to avoid bias. Reproductive success was measured in terms of the number of fledgling(s) per female throughout the breeding season.

This study included eight feeder-using females and nine non-feeder-using females (all except three were individually colour-banded, and the three unbanded individuals were located $>1 \mathrm{~km}$ apart; Table 1). We were aware of at least another 11 females that were present at Maungatautari that season (10 of which were first-year females), but did not include these to keep the sample size manageable. We selected the females to monitor so that the number of feeder-users vs non-feeder-users was balanced, and the number of first-year vs older females was as balanced as possible. However, it was not possible to

Table 1. Reproductive success of hihi in the 2012/13 breeding season at Maungatautari in relation to feeder use and age. Zeros (0) indicate non-feeder-using females and first-year females, whereas ones (1) represent feeder-using females and older females. Blank cells indicate that no second clutch was detected.

\begin{tabular}{|c|c|c|c|c|c|c|}
\hline Female & $\begin{array}{c}\text { Feeder } \\
\text { use }\end{array}$ & $\begin{array}{c}\text { Female } \\
\text { age }\end{array}$ & $\begin{array}{c}\text { Nest } \\
\text { initiation }\end{array}$ & $1^{\text {st }}$ clutch & $\begin{array}{l}\text { umber fledg } \\
2^{\text {nd }} \text { clutch }\end{array}$ & Total \\
\hline UB1 & 0 & 0 & 29/11/2012 & 0 & 0 & 0 \\
\hline BR-OM & 0 & 0 & 4/12/2012 & 2 & 2 & 4 \\
\hline UB2 & 0 & 0 & $5 / 12 / 2012$ & 0 & 1 & 1 \\
\hline OO-OM & 0 & 0 & $6 / 12 / 2012$ & 2 & 0 & 2 \\
\hline UB3 & 0 & 1 & $26 / 11 / 2012$ & 3 & 2 & 5 \\
\hline OY-GM & 0 & 1 & $4 / 12 / 2012$ & 0 & & 0 \\
\hline RN-GM & 0 & 1 & $6 / 12 / 2012$ & 1 & 2 & 3 \\
\hline WM-ON & 0 & 1 & $12 / 12 / 2012$ & 0 & 3 & 3 \\
\hline OY-WM & 0 & 1 & $18 / 12 / 2012$ & 0 & & 0 \\
\hline GW-OM & 1 & 0 & $24 / 12 / 2012$ & 4 & 2 & 6 \\
\hline RR-GM & 1 & 1 & $2 / 11 / 2012$ & 3 & & 3 \\
\hline VM-R & 1 & 1 & $15 / 11 / 2012$ & 1 & & 1 \\
\hline YM-RB & 1 & 1 & $18 / 11 / 2012$ & 4 & & 4 \\
\hline HM-JO & 1 & 1 & $22 / 11 / 2012$ & 2 & & 2 \\
\hline OW-GM & 1 & 1 & $23 / 11 / 2012$ & 3 & & 3 \\
\hline GY-VM & 1 & 1 & 23/11/2012 & 4 & 1 & 5 \\
\hline WN-RM & 1 & 1 & 2/12/2012 & 3 & & 3 \\
\hline
\end{tabular}


completely avoid an imbalance in age structure. Of the eight feeder-using females, seven were aged between 2 and 4 years, and the eighth was in her first year. Four were founders and four Maungatautari-bred. Of the nine non-feeder-using females, five were aged between 2 and 4 years (two were founders) and four were first-year Maungatautari-bred birds. This difference is probably due to young females establishing territories further from feeders and being unfamiliar with them.

Territory locations were known from a concurrent study (Richardson \& Ewen 2016). The 17 selected territories were closely monitored in order to determine nest initiation dates (usually by back-counting once incubation/hatching was confirmed) and to obtain an accurate count of the number of young fledged by each female over the breeding season. Nests were located through the use of behavioural cues, such as females frequently returning to the same location or males concentrating their territorial calling around a specific tree. Once a nest was located, weekly 1.5 hour observations were conducted to determine nest stage. As fledging time grew closer nests were checked daily, so that fledglings could be counted either on the day, or the day after fledging. Fledglings were located and counted by listening for their distinctive high-pitched begging calls and observing adult provisioning behaviour. If fledging was asynchronous, the observer would return daily to count the fledglings until the adults no longer visited the nest.

\section{Data analysis}

Generalised linear models were used to estimate the effect that feeder-use and age (first-year vs older) had on the reproductive success and initiation dates of first clutches of female hihi at Maungatautari. For models that examined reproductive success, Poisson regression (log link and Poisson error term) was used. The model that examined nest initiation date used a linear regression (identity link function and normal error term). Two separate analyses were performed for reproductive success. In the first, reproductive success was measured in terms of the number of young fledged by each female in her first clutch, allowing comparison with similar data from Hauturu (Makan et al. 2014). In order to obtain the most useful measure for population growth, the second analysis defined reproductive success as the total number of young fledged across all clutches within the breeding season.

\section{Results}

Feeder-use had the most pronounced effect on the number of fledglings a female produced in her first-clutch attempt. Feederusing females fledged an average of 3.0 fledglings from their first clutches, whereas non-feeder-users fledged an average of 0.9. Taking age into account, feeder-using females were estimated to fledge 3.7 times as many first-clutch fledglings than non-feeder-users (95\% CI 1.6-8.8) (Table 2, Fig. 2). The effect of feeder-use on the total number of fledglings was less pronounced. Feeder-using females had an average of 3.4 fledglings over the season whereas non-feeder-users had an average of 2.0. Taking age into account, feeder-users were estimated to produce 1.8 times as many fledglings over the breeding season (95\% CI 1.0-3.5) (Table 2, Fig. 2). This less pronounced difference over the whole season was largely due to non-feeder-using females increasing their total number of young fledged through a second clutch. All non-feeder-using females observed after their first-clutch attempt (seven of the nine females) attempted a second clutch, whereas only two of the eight feeder-using females attempted a second clutch. The difference in reproductive success between the two groups is primarily explained by nest success, i.e. the proportion of nests fledging one or more young. The 10 nest attempts by feeder-using females were all successful, compared to the failure of seven of the 16 nest attempts of non-feeder-using females. This difference was especially pronounced in first nest attempts, with five of the nine nest attempts of nonfeeder-using females failing. There was no indication that age affected reproductive success, either for first clutches or for the whole season (Table 2).

Although there were no statistically significant effects on nest initiation (Table 3), feeder-using females began their first clutch attempt on average 10 days sooner than non-feeder-using females, and second-year or older females initiated their first clutch attempt on average 7 days sooner than first-year females (Tables $1 \& 3$ ). The lack of significant results is potentially due to the two effects working in the model reducing power so that sample sizes were insufficient.

\section{Discussion}

Feeder-use influenced hihi reproductive success at Maungatautari, mainly by significantly increasing the number of chicks fledged from first clutches. No feeder-using female experienced a nest failure, whereas $44 \%$ of all non-feederusing female nests failed during the 2012/13 breeding season. Feeder-use appeared to have a particularly strong impact on first clutch success, since without its use $56 \%$ of first clutches failed. The inaccessibility of the nests prevented us from determining the cause of nest failure. However, hihi nestling
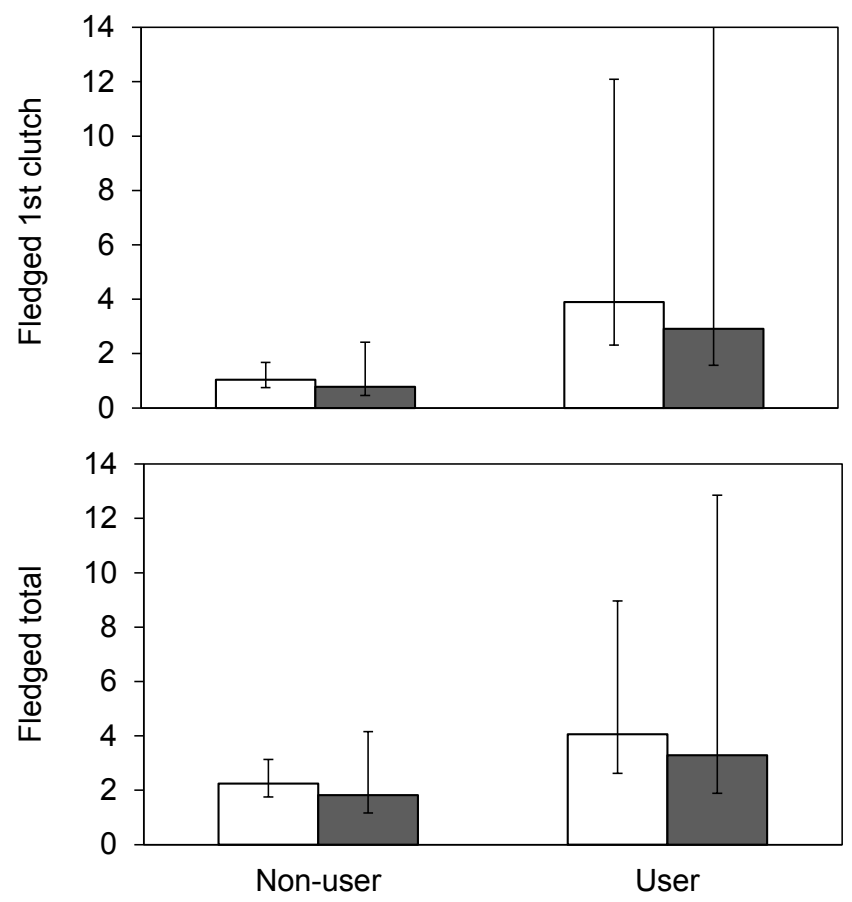

Figure 2. Effect of feeder-use on productivity of female hihi at Maungatauri Ecological Island based on the parameter estimates shown in Table 2. White bars show first-year females and grey bars show older females. Vertical bars show standard errors. 
Table 2. Effects of feeder-use and age on reproductive success of female hihi at Maungatautari, as estimated using Poisson regression. Real values show the mean number of fledglings for the intercept (non-feeder-using first-year females), and the proportional effects of age (older/first-year) and feeder use (users/non-users).

\begin{tabular}{llrrrrrrr}
\hline & \multicolumn{3}{c}{ Log-transformed } & \multicolumn{3}{c}{ Real } & & \\
Response var. & Parameter & Est. & $2.5 \%$ & $97.5 \%$ & Est. & $2.5 \%$ & $97.5 \%$ & $P$ \\
\hline Fledged 1 $1^{\text {st }}$ clutch & Intercept & 0.04 & -0.77 & 0.84 & 1.0 & 0.5 & 2.3 & 0.502 \\
& Age & -0.29 & -1.15 & 0.56 & 0.8 & 0.3 & 1.8 & 0.005 \\
\hline Fledged total & Feeder use & 1.32 & 0.46 & 2.17 & 3.7 & 1.6 & 8.8 & \\
& Intercept & 0.81 & 0.23 & 1.39 & 2.2 & 1.3 & 4.0 & 0.551 \\
& Age & -0.21 & -0.91 & 0.48 & 0.8 & 0.4 & 1.6 & 0.070 \\
\hline
\end{tabular}

Table 3. Effects of feeder-use and age on nest initiation dates of female hihi at Maungatautari, as estimated using linear regression. Values show the mean number of days since 2 November 2012 for the intercept (non-feeder-using firstyear females), and additive effects of age and feeder use.

\begin{tabular}{lrrrc}
\hline Parameter & Estimate & $2.5 \%$ & $97.5 \%$ & $P$ \\
\hline Intercept & 37.53 & 27.48 & 47.58 & \\
Age & -7.15 & -19.60 & 5.29 & 0.279 \\
Feeder use & -9.65 & -21.00 & 1.71 & 0.118
\end{tabular}

mortality may be caused by starvation, as well as a variety of pathogens, heavy nest mite (Ornithonyssus bursa) loads, or some combination of these factors (Armstrong et al. 2007; Ewen et al. 2009; Rippon 2010). The improved success of feeder-using females is presumably due to supplementary feeding increasing nestling provisioning rates (Makan 2006).

\section{Effect of supplementary feeding in mature vs regenerating forest}

Makan et al.(2014) compared first-clutch reproductive success between Hauturu (mature forest) and three other island sites at varying levels of forest regeneration (Mokoia, Tiritiri Matangi, Kapiti). Their analysis suggested an interaction between effects of habitat complexity (which increases with forest maturity) and supplementary feeding on hihi reproductive success. We predicted that because of Maungatautari's complex forest structure, supplementary feeding would have less impact on reproductive success than in the three regenerating forest sites where it has previously been assessed. Due to apparent similarities in forest maturity, we expected the first clutches of Maungatautari's non-feeder-using females to be comparable with the number of fledglings produced in first clutches by females nesting on Hauturu. Counter to expectations, our results were most similar to Mokoia (the site with the lowest forest maturity) with non-feeder-using females fledging 0.9 chicks at Maungatautari and 0.8 chicks on Mokoia; and with feederusing females fledging 3.0 chicks at Maungatautari and 2.8 chicks on Mokoia (Fig. 3). This result suggests that it is more than forest complexity that is vital to reproductive success.

It is important to be aware that comparisons based on first clutches may be slightly misleading. Makan et al. (2014) necessarily used first-clutch data because data on total numbers of fledglings over the breeding season were not available for
Hauturu or Kapiti. However, this assessment may exaggerate the impact of supplementary feeding, because it does not account for the ability of females to improve their reproductive output through second clutches, an issue recognised by Makan et al. (2014). Our results illustrate this distinctly, as feederusing females produced 3.7 times as many fledglings in first clutches in comparison to 1.8 times as many fledglings over the whole breeding season. It is clearly preferable to consider the entire breeding season, as it is the total number of fledglings produced that is important to population growth. Although non-feeder-using females were able to compensate for their lower first-clutch success by attempting second clutches, their breeding efficiency was still much lower than feeder-using females. Reproduction is costly and this additional effort may have long-term negative effects, such as decreased survival (Verhulst 1998).

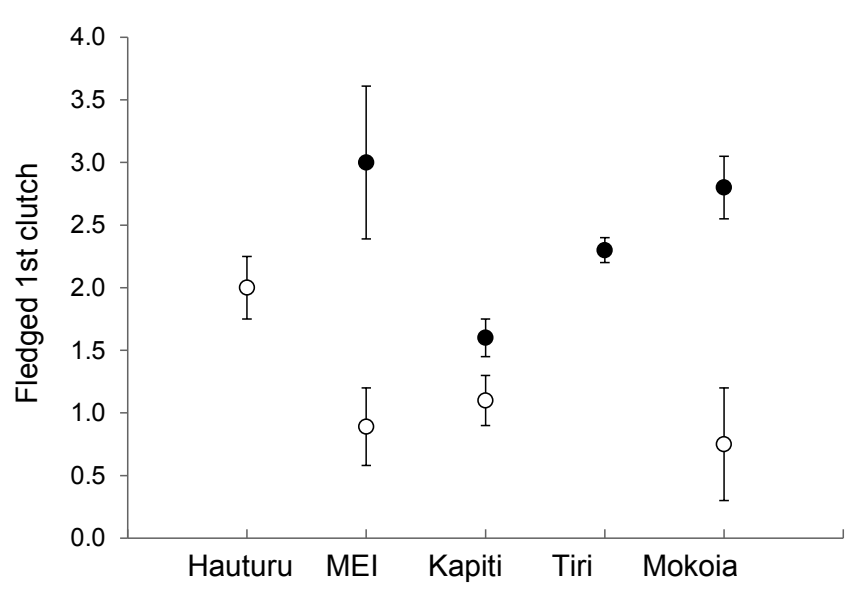

Figure 3. Numbers of chicks fledged (mean $\pm \mathrm{SE}$ ) from first clutches in different hihi populations. For Maungatautari (MEI), closed circles show number of fledglings of feeder-using individuals and open circles show number of fledglings from non-feeder-using individuals. For the other sites, closed circles show years when feeders were available and closed circles show years when no feeders were available. The estimates for MEI are from the data shown in Table 1, and the estimates from the other sites are copied from Makan et al. (2104). Habitat age and management increases from right to the left. 


\section{Effects of age and confounding factors}

The lack of a strong age effect was unexpected, since previous studies have found that second-year and older females had improved reproductive success in comparison to first-year females, primarily due to delayed territory establishment in first-year birds (Armstrong et al. 2002; Low et al. 2007). The only suggestion of an age effect from our models, though at a non-significant level, was on first-clutch initiation. Second year and older females initiated their clutches on average 7 days earlier than first year females, similar to findings from Low et al. (2007). The lack of an age effect on numbers of fledglings produced can potentially be explained by the differences in either habitat quality or population density between sites, which are known to alter age-dependent reproduction (Martin 1995). Potentially there are a greater number of territories available at Maungatautari, which would decrease competition between females allowing younger individuals, who are typically subordinate to older individuals, to secure territories earlier in the breeding season (Low et al. 2007).

Our results show that future studies need to include the total number of fledglings produced in the breeding season to gain the most accurate understanding of the effects of management on hihi reproductive success. Duplicating a study over multiple years would also be useful because it would eliminate some of the uncertainty caused by seasonal variation in fruit/flower abundance. It was incidentally observed during this study that it was a very dry breeding season and that some of the common flowering species at Maungatautari had a low yield year (e.g. rewarewa and toropapa, Alseuosmia spp.). This dryness could potentially mean that food availability was lower than normal, exacerbating the effects of supplementary feeding during the 2012/13 breeding season. By running the study for multiple years it would provide a clearer picture of female reproductive patterns at a specific site.

As with any uncontrolled experiment, there is potential for confounding factors to exist. The availability of the hihi's preferred breeding habitat across the lower slopes of Maungatautari led us to believe that differences in habitat quality would not significantly affect female hihi reproductive success. Regardless, we attempted to locate nests of feeder-using and non-feeder-using females in close proximity to each other in an effort to account for variations in microclimate and habitat quality. Unfortunately, this was not always possible, especially on the southern side of the mountain where the majority of females present were feeder-users. Thus, we could not rule out the possibility that the southern portion of Maungatautari's habitat may have some undetermined characteristic(s) that benefits reproductive success. Furthermore, high-quality females could be more likely to secure territories close to feeders, so their greater reproductive success could potentially be linked to their better quality rather than the use of the feeders.

\section{Management implications}

Our results do not support the prediction that supplementary feeder use will have a lesser impact at mature forest sites, in comparison to regenerating forest sites. Instead, they suggest that female reproductive success may consistently increase where supplementary food is available, regardless of forest age or maturity. This outcome has important ramifications for hihi management. Supplementary feeders should perhaps be available at all translocation sites regardless of habitat type, at least early in the establishment phase. While hihi can clearly reproduce to some extent without supplementary food, it is clear that supplementary food increases reproductive output, and may be needed for population growth. In 2012/13, estimates of population growth rate for the Maungatautari hihi population were 1.21 (Richardson 2015). Without supplementary feeding, this would certainly have been lower, probably resulting in population decline.

The need for faster population growth, which could potentially be achieved by using additional feeders, needs to be balanced against alternative objectives in hihi recovery including reducing management costs and pursuing a more natural setting for hihi populations (i.e. less artificial feeding support). Such multi-objective trade-offs have been used to revise feeding of hihi on Kapiti Island (Ewen et al. 2015). As the Maungatautari population establishes, progressively fewer hihi are using the feeders, presumably an outcome of spatial expansion of the population away from the southern part of the mountain. The effects of this on population growth, and what response managers should or could take, are the continued focus of hihi recovery.

\section{Acknowledgements}

We would like to thank Debbie Leigh, Scott Freeman, and all the others who assisted with fieldwork. We are also grateful for the funding and support received from the Massey University Research Fund and the Zoological Society of London, and to the Maungatautari Ecological Island Trust, Ngāti Korokī Kahukura, Ngāti Hauā, and Raukawa iwi for permission to conduct research at the reserve, and Maungatautari landowners for allowing access to the site. We also thank Jo Monks, Carey Knox and an anonymous referee for comments on the manuscript.

\section{References}

Armstrong DP, Ewen JG 2001. Testing for food limitation in reintroduced hihi populations: contrasting results for two islands. Pacific Conservation Biology 7: 87-92.

Armstrong DP, Perrott JK 2000. An experiment testing whether condition and survival are limited by food supply in a reintroduced hihi population. Conservation Biology 14: 1171-1181.

Armstrong DP, Davidson RS, Dimond WJ, Perrott JK, Castro I, Ewen JG, Griffiths R, Taylor J 2002. Population dynamics of reintroduced forest birds on New Zealand islands. Journal of Biogeography 29: 609-621.

Armstrong DP, Castro I, Griffiths R 2007. Using adaptive management to determine requirements of reintroduced populations: the case of the New Zealand hihi. Journal of Applied Ecology 44: 953-962.

Blanco G, Lemus JA, García-Montijano M 2011. When conservation management becomes contraindicated: impact of food supplementation on health of endangered wildlife. Ecological Applications 21: 2469-2477.

Buller WLR 1888. A history of the birds of New Zealand. London, UK. 359 p.

Castro I 1995. Behavioural ecology and management of hihi Notiomystis cincta, an endemic New Zealand honeyeater. $\mathrm{PhD}$ thesis, Massey University, Palmerston North, New Zealand. $136 \mathrm{p}$.

Chauvenet A, Ewen J, Armstrong D, Coulson T, Blackburn T, 
Adams L, Walker L, Pettorelli N 2012. Does supplemental feeding affect the viability of translocated populations? The example of the hihi. Animal Conservation 15: 337-350.

Converse SJ, Moore CT, Armstrong DP 2013. Demographics of reintroduced populations: estimation, modeling, and decision analysis. The Journal of Wildlife Management 77: 1081-1093.

Cortés-Avizanda A, Carrete M, Donázar JA 2010. Managing supplementary feeding for avian scavengers: guidelines for optimal design using ecological criteria. Biological Conservation 143: 1707-1715.

Driskell A, Christidis L, Gill BJ, Boles WE, Barker KF, Longmore NW 2007. A new endemic family on New Zealand passerine birds: adding heat to a biodiversity hotspot. Australian Journal of Zoology 55: 73-78.

Ewen JG, Thorogood R, Karadas F, Pappas AC, Surai PF 2006. Influences of carotenoid supplementation on the integrated antioxidant system of a free living endangered passerine, the hihi (Notiomystis cincta). Comparative Biochemistry and Physiology Part A: Molecular \& Integrative Physiology 143: 149-154.

Ewen JG, Thorogood R, Brekke P, Cassey P, Karadas F, Armstrong DP 2009. Maternally invested carotenoids compensate costly ectoparasitism in the hihi. Proceedings of the National Academy of Sciences 106: 12798-12802.

Ewen JG, Parker KA, Richardson K, Armstrong D, SmutsKennedy C 2011. Translocation of hihi Notiomystis cincta to Maungatautari, a mainland reserve protected by a predator-exclusion fence, Waikato, New Zealand. Conservation Evidence 8: 58-65.

Ewen JG, Walker L, Canessa S, Groombridge JJ 2015. Improving supplementary feeding in species conservation. Conservation Biology 29: 341-349.

Hansen AJ 1987. Regulation of bald eagle reproductive rates in southeast Alaska. Ecology 68: 1387-1392.

Higgins PJ, Peter JM, Steele WK 2001. Handbook of Australian, New Zealand and Antarctic birds. Volume 5: tyrant-flycatchers to chats. Melbourne, Oxford University Press. 1269 p.

Innes J, Kelly D, Overton JM, Gillies C 2010. Predation and other factors currently limiting New Zealand forest birds. New Zealand Journal of Ecology 34: 86-114.

López-Bao JV, Palomares F, Rodríguez A, Delibes PF 2010. Effects of food supplementation on home-range size, reproductive success, productivity and recruitment in a small population of Iberian lynx. Animal Conservation 13: $35-42$.

Low M, Joy MK, Makan T 2006. Using regression trees to predict patterns of male provisioning in the stitchbird (hihi). Animal Behaviour 71: 1057-1068.

Low M, Pärt T, Forslund P 2007. Age-specific variation in reproduction is largely explained by the timing of territory establishment in the New Zealand stitchbird Notiomystis cincta. Journal of Animal Ecology 76: 459-470.

McQueen JC, Smuts-Kennedy C, Collier K, Clarkson BD, Burns B, MacGibbon R 2004. An ecological restoration plan for Maungatautari, 2003-2004; working document. Hamilton, New Zealand, Centre for Biodiversity and Ecology Research, Department of Biological Sciences,
University of Waikato. $111 \mathrm{p}$.

Makan T 2006. The stitchbird (hihi-Notiomystis Cincta) and its habitat: effects on nestling behaviour and reproductive success. Unpublished Masters thesis, Massey University, Palmerston North, New Zealand. 86 p.

Makan T, Castro I, Robertson AW, Joy MK, Low M 2014. Habitat complexity and management intensity positively influence fledging success in the endangered hihi (Notiomystis cincta). New Zealand Journal of Ecology 38: 53-63.

Martin K 1995. Patterns and mechanisms for age-dependent reproduction and survival in birds. American Zoologist 35: 340-48.

Martínez-Abraín A, Oro D 2013. Preventing the development of dogmatic approaches in conservation biology: a review. Biological Conservation 159: 539-547.

Oro D, Margalida A, Carrete M, Heredia R, Donázar JA 2008. Testing the goodness of supplementary feeding to enhance population viability in an endangered vulture. PLoS One 3: 4084.

Pérez-González J, Margalida A, Sanchez R, Oria J 2006. Supplementary feeding as an effective tool for improving breeding success in the Spanish imperial eagle (Aquila adalberti). Biological Conservation 29: 477-486.

Pérez-González J, Barbosa AM, Carranza J, Torres-Porras J 2010. Relative effect of food supplementation and natural resources on female red deer distribution in a Mediterranean ecosystem. The Journal of Wildlife Management 74: 1701-1708.

Richardson KM 2015. Dispersal: the effects of phenotype and habitat selection in reintroduced populations. Unpublished $\mathrm{PhD}$ thesis, Massey University, Palmerston North, New Zealand.

Richardson KM, Ewen JG 2016. Habitat selection in a reintroduced population: social effects differ between natal and post-release dispersal. Animal Conservation. DOI: $10.1111 /$ acv. 12257.

Rippon RJ 2010. Nestling mortality in a translocated population of hihi/stitchbirds (Notiomystis cincta). Unpublished MSc thesis, Massey University, Palmerston North, New Zealand. $117 \mathrm{p}$.

Robb GN, McDonald RA, Chamberlain DE, Bearhop S 2011. Food for thought: supplementary feeding as a driver of ecological change in avian populations. Frontiers in Ecology and the Environment 6: 476-484.

Schoech SJ, Bridge ES, Boughton RK, Reynolds SJ 2008. Food supplementation: a tool to increase reproductive output? A case study in the threatened Florida Scrub-Jay. Biological Conservation 141: 162-173.

Shea K 1998. Management of populations in conservation, harvesting and control. Trends in Ecology \& Evolution 13: 371-375.

Taylor S, Castro I, Griffiths R 2005. Hihi/stitchbird(Notiomystis cincta) recovery plan 2004-09. Wellington, New Zealand, Department of Conservation. $31 \mathrm{p}$.

Verhulst S 1998. Multiple breeding in the great tit. The costs of rearing a second clutch. Functional Ecology 12: 132-140.

Ziegltrum GJ 2008. Impacts of the black bear supplemental feeding program on ecology in western Washington. Human-Wildlife Interactions Paper 60.

Editorial board member: Jo Monks

Received 1 June 2016; accepted 8 September 2016 